\title{
Genetic Analysis of Oxytetracycline Resistance in Bacillus subtilis by means of Transformation
}

\author{
By M. POLSINELLI \\ Istituto di Genetica, Università, Pavia, Italy
}

(Received 9 April 1964)

\begin{abstract}
SUMMARY
Mutants of Bacillus subtilis resistant to oxytetracycline were produced and DNA prepared from them was then used for transforming a sensitive strain. DNA from a first-step mutant seemed to transmit a single genetic factor. On the other hand, bacteria, transformed with DNA from a second-step mutant, showed a trimodal distribution of resistance, suggesting that at least two factors were involved in the process. Transformation with DNA from clones belonging to the first and second peaks of the distribution showed that such clones transmitted a single genetic factor for oxytetracycline resistance, while DNA from clones of the third peak transformed sensitive bacteria in a way similar to that of the second step mutant. The results suggested that the two factors are linked and that they had a cumulative effect on drug resistance.
\end{abstract}

\section{INTRODUCTION}

Drug resistance in micro-organisms is known to be under genetic control. Two main types of chromosomal resistance have been described: one-step resistance, when only one mutation seems to be sufficient to permit the bacterium to resist high doses of drug, as in the case for streptomycin (Demerec, 1948); and stepwise or multi-step resistance, when organisms need more than one mutation to increase their resistance, as for penicillin(Demerec, 1945) and chloramphenicolr esistance (Cavalli \& Maccacaro, 1950). One gene is presumed to control the mechanism of resistance in the first type, many genes in the second. The genetic analysis of drug resistance has also been approached by means of transformation. Hotchkiss (1951), working with Pneumococcus, obtained three different degrees of penicillin resistance by transformation with DNA from a multi-step highly resistant strain. His results were in agreement with the suggestion by Demerec (1945) that multi-step drug resistance in bacteria originates in successive mutational steps. Later on Hotchkiss \& Evans (1957) reported detailed studies on genetic control of sulphonamide resistance in a highly resistant mutant of Pneumococcus. They showed that the high sulphonamide resistance in that strain was under the control of three linked units.

Ravin \& Iyer (1961), studying erythromycin resistance in five different spontaneous mutants of Pneumococcus by means of transformation, concluded that three distinct degrees of resistance were present in those mutants; the genetic factors were linked and different combinations of the mutations might have either an antagonistic, synergistic or non-synergistic effect on the phenotypic expression of the resistance.

In a mutant of Haemophilus influenzae resistant up to $700 \mu \mathrm{g}$. streptomycin $/ \mathrm{ml}$. 
Hsu \& Herriott (1961) found that resistance was controlled by at least two unlinked genes. These two genes, when separated in different bacteria, gave a resistance to 10 and $100 \mu \mathrm{g}$. streptomycin $/ \mathrm{ml}$., respectively. When they entered the same bacterium, there was an almost multiplicative effect and the organism resisted up to $700 \mu \mathrm{g}$. streptomycin $/ \mathrm{ml}$. In the present paper are reported some results on the genetic analysis of the stepwise resistance to oxytetracycline (OT) in Bacillus subtilis.

\section{METHODS}

Media. Difco Bacto-Penassay; Spizizen minimal medium (1958) for preparing competent bacteria; medium 40 (Magni \& von Borstel, 1962), a minimal solid medium adjusted to $\mathrm{pH} 7$, always fortified with tryptophan $(20 \mu \mathrm{g} . / \mathrm{ml}$.) and histidine $(20 \mu \mathrm{g} . / \mathrm{ml}$.) for all platings.

\section{Table 1. Mutants of Bacillus subtilis used}

\begin{tabular}{|c|c|c|}
\hline Strain & Genotype & Derivation \\
\hline SB 25 & $h i s_{2} \operatorname{try}_{2}$ & Nester \& Lederberg (1961) \\
\hline SB 57 & $h i s_{2} t r y_{2} O T-r(120 \mu \mathrm{g} . / \mathrm{ml})$. & $\begin{array}{l}\text { From strain SB } 25 \text { by selection on medium } \\
40+\text { oxytetracycline } 40 \mu \mathrm{g} . / \mathrm{ml} \text {. }\end{array}$ \\
\hline SB 151 & $h i s_{2} t r y_{8} O T-r(250 \mu \mathrm{g} . / \mathrm{ml})$. & $\begin{array}{l}\text { From strain sB } 57 \text { by selection on medium } \\
40+\text { oxytetracycline } 150 \mu \mathrm{g} . / \mathrm{ml} \text {. }\end{array}$ \\
\hline $\begin{array}{l}\text { SB } 151 / 1 \\
\text { SB } 151 / 5 \\
\text { SB } 151 / 8\end{array}$ & 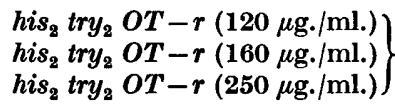 & $\begin{array}{l}\text { From strain sB } 25 \text { treated with DNA from } \\
\text { strain sB } 151\end{array}$ \\
\hline
\end{tabular}

Selection of oxytetracycline-resistant mutants of Bacillus subtilis. A culture of Bacillus subtilis sB 25 (kindly supplied by Dr J. Lederberg), grown in Penassay broth at $37^{\circ}$ for $15 \mathrm{hr}$, was centrifuged and resuspended in saline at a concentration of $4 \times 10^{9}$ bacteria $/ \mathrm{ml}$; $0.1 \mathrm{ml}$. samples of this suspension were plated on medium 40 supplemented with $40 \mu \mathrm{g}$. oxytetracycline $/ \mathrm{ml}$. (in this medium strain sB 25 is inhibited by $15 \mu \mathrm{g}$. oxytetracycline $/ \mathrm{ml}$.). After incubation for $48 \mathrm{hr}$ at $37^{\circ}, 50$ colonies were picked and streaked on medium 40 supplemented with different concentrations of oxytetracycline. The 50 tested colonies showed, after $24 \mathrm{hr}$, normal growth on medium containing up to $120 \mu \mathrm{g}$. oxytetracycline $/ \mathrm{ml}$.; these were presumed to be first-step mutants. Second-step mutants, resistant to about $250 \mu \mathrm{g}$. oxytetracycline $/ \mathrm{ml}$., were derived from a first-step mutant, sB 57, also by selection on solid medium, containing $150 \mu \mathrm{g}$. oxytetracyline $/ \mathrm{ml}$. All the degrees of resistance were tested by the streak technique.

DNA preparation, transformation procedure and transformant selection. DNA from donor resistant mutants was extracted by following the technique described by Ephrati-Elizur, Srinivasan \& Zamenhof(1961). Competent bacteria of the recipient strain were prepared according to the procedure of Young \& Spizizen (1961). Competent bacteria were treated with $0 \cdot 1 \mu \mathrm{g}$. DNA/ml. ; after incubation for $30 \mathrm{~min}$. deoxyribonuclease (Sigma; $20 \mu \mathrm{g} . / \mathrm{ml}$.) was added, and bacteria were plated after a further $60 \mathrm{~min}$. The selective medium was supplemented with $40 \mu \mathrm{g}$. oxytetracycline $/ \mathrm{ml}$., 
the minimal inhibitory concentration, in order to recover all the resistant transformants. The degree of resistance of colonies grown on selective medium was individually tested on different concentrations of oxytetracycline.

\section{RESULTS}

According to the procedure described in the preceding paragraph, the strain SB 25 of Bacillus subtilis was transformed with DNA from strain sB 57 obtained by a single step of selection (resistant to $120 \mu \mathrm{g}$. oxytetracycline $/ \mathrm{ml}$.) and with DNA from strain SB 151 obtained from the latter by means of a second step of selection and resistant to about $250 \mu \mathrm{g}$. oxytetracycline $/ \mathrm{ml}$. All the transformed bacteria were selected, in both experiments, on medium 40 containing $40 \mu \mathrm{g}$. oxytetracycline/ $\mathrm{ml}$. and afterwards many of the transformant colonies were tested for their resistance to this compound (Table 2). The efficiency of transformation of these strains is reported in the first two lines of Table 2 and the distribution of the resistance of the transformant colonies is shown in Figs. 1 and 2, respectively.

From Fig. 1 it can be seen that the transformants with DNA from the strain made resistant by a single step were very uniform, as they showed a single-peaked distribution with the mode at $120 \mu \mathrm{g}$. oxytetracycline/ml., repeating exactly the phenotypic distribution of resistance of strain sB 57. On the other hand the transformants with DNA from the strain sB 151, obtained by two steps of selection, showed (Fig. 2) a trimodal distribution with modes at the first, second and third peaks of oxytetracycline 120,160 and $250 \mu \mathrm{g} . / \mathrm{ml}$, , respectively. From the genetic point of view, these results might be interpreted as due to two factors with a cumulative effect, or to three factors not showing any synergistic properties.

Table 2. Transformation for oxytetracycline resistance with $D N A$ from different resistant mutants of Bacillus subtilis

\begin{tabular}{|c|c|c|c|c|c|}
\hline \multirow[b]{2}{*}{ Donor strains } & \multicolumn{2}{|c|}{$\begin{array}{l}\text { Efficiency of } \\
\text { transformation }\end{array}$} & \multicolumn{2}{|c|}{$\begin{array}{c}\text { Controls without } \\
\text { DNA }\end{array}$} & \multirow{2}{*}{$\begin{array}{c}\text { Distribution } \\
\text { of } \\
\text { resistance } \\
\text { among } \\
\text { transformant } \\
\text { colonies }\end{array}$} \\
\hline & $\begin{array}{c}\text { No. } \\
\text { trans- } \\
\text { formant } \\
\text { colonies }\end{array}$ & $\begin{array}{c}\text { No. } \\
\text { plated } \\
\text { bacteria }\end{array}$ & $\overbrace{\begin{array}{c}\text { No. } \\
\text { resistant } \\
\text { colonies }\end{array}}$ & $\begin{array}{c}\text { No. } \\
\text { plated } \\
\text { bacteria }\end{array}$ & \\
\hline sB $57 O T-r(120 \mu \mathrm{g} . / \mathrm{ml})$. & 268 & $1.2 \times 10^{6}$ & 1 & $1.2 \times 10^{8}$ & See Fig. 1 \\
\hline sB $151 O T-\tau(250 \mu \mathrm{g} . / \mathrm{ml})$. & 2842 & $8.8 \times 10^{7}$ & 0 & $6.9 \times 10^{7}$ & See Fig. 2 \\
\hline SB 151/1 OT $-r(120 \mu \mathrm{g} . / \mathrm{ml})$. & 820 & $2.8 \times 10^{7}$ & $\mathbf{0}$ & $5.4 \times 10^{7}$ & See Fig. 3 \\
\hline SB 151 $/ 5 O T-r(160 \mu \mathrm{g} . / \mathrm{ml})$. & 1786 & $2 \cdot 4 \times 10^{7}$ & 0 & $1.4 \times 10^{8}$ & See Fig. 4 \\
\hline $\mathrm{sB} 151 / 8 O T-r(250 \mu \mathrm{g} . / \mathrm{ml})$. & 612 & $1 \cdot 1 \times 10^{7}$ & 0 & $1.4 \times 10^{8}$ & See Fig. 5 \\
\hline $\mathrm{SB} 151 / 1+\mathrm{SB} 151 / 5$ & 1255 & $3.9 \times 10^{7}$ & 2 & $4 \times 10^{8}$ & See Fig. 6 \\
\hline
\end{tabular}

Transformation for resistance to oxytetracyline with $\mathrm{DNA}$ from transformant colonies. Three clones obtained in the experiment shown in Fig. 2 were used as donor strains. The clones were: SB 151/1 from the first peak (resistant to $120 \mu \mathrm{g}$. oxytetracycline/ml.); SB 151/5 from the second peak (resistant to $160 \mu \mathrm{g}$. oxytetracycline/ ml.); sB 151/8 from the third peak (resistant to $250 \mu \mathrm{g}$. oxytetracycline/ml.).

The efficiency of transformation with DNA extracted from these clones is reported in the third, fourth, fifth and sixth lines of Table 2. The distribution of the resistance between clones is shown in Figs. 3, 4, 5 . 


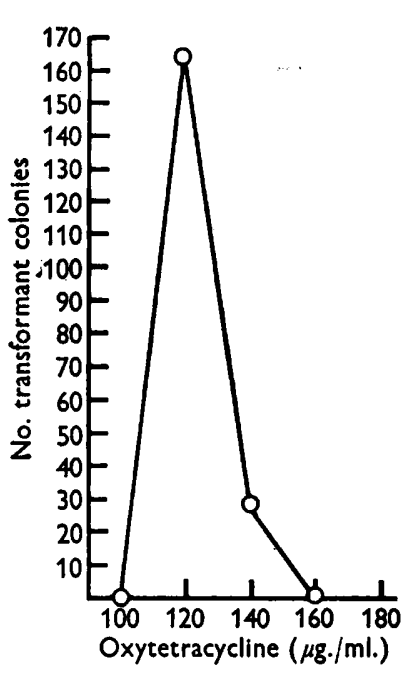

Fig. 1

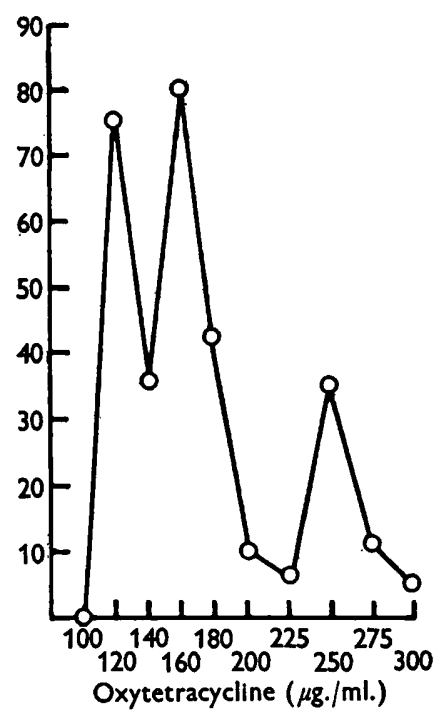

Fig. 2

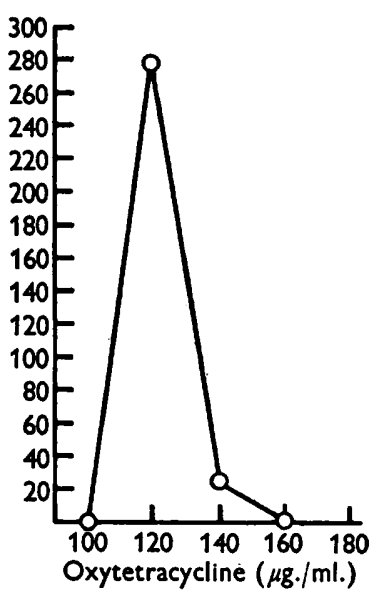

Fig. 3

Fig. 1. Distribution of resistance between 192 transformant colonies, when DNA from the first-step resistant mutant was used.

Fig. 2. Distribution of resistance between 298 transformant colonies, when DNA from the second-step resistant mutant was used.

Fig. 3. Distribution of resistance between 300 transformant colonies when DNA from the first peak (Fig. 2) was used.

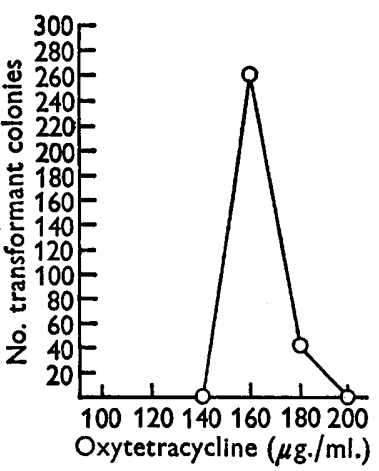

Fig. 4

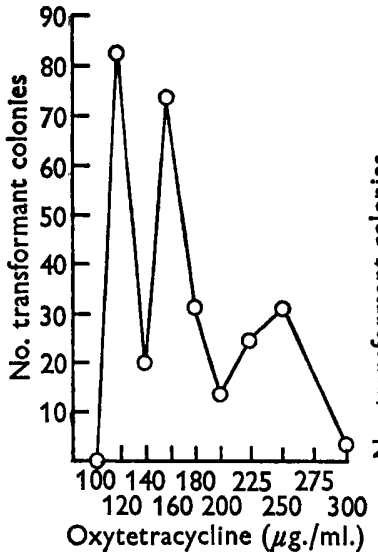

Fig. 5

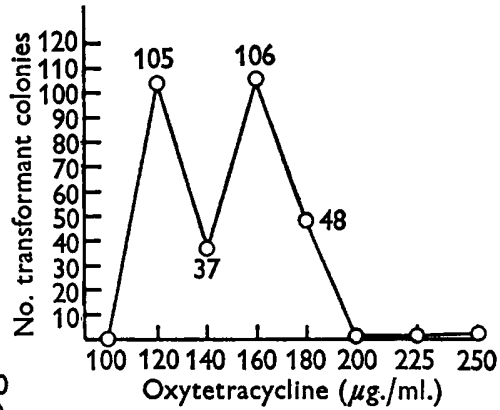

Fig. 6

Fig. 4. Distribution of resistance between 300 transformant colonies, when DNA from the second peak (Fig. 2) was used.

Fig. 5. Distribution of resistance between 300 transformant colonies, when DNA from the third peak (Fig. 2) was used.

Fig. 6. Distribution of resistance between 300 transformant colonies when a mixture of two DNAs (from first and second peaks) was used. 
From this, it can be seen that the transformants with DNA from the first peak gave the same distribution as strain sB 57, a single-step resistant mutant, with mode at $120 \mu \mathrm{g}$. oxytetracycline $/ \mathrm{ml}$. Also the clone of the second peak seemed to produce a genetically uniform DNA, which transformed for a modal resistance of $160 \mu \mathrm{g}$. oxytetracycline $/ \mathrm{ml}$. The use of a mixture of the DNAs obtained from the first and second peak gave a bimodal resistance distribution (Fig. 6) with modes corresponding to the two original peaks and only four colonies out of $\mathbf{3 0 0}$ outside the distribution. For the present analysis the distribution of the resistance of the transformants with DNA from the third peak is very interesting, since it repeats the same trimodality already shown in Fig. 2, but by using as donor the DNA from the second-step resistant mutant.

\section{DISCUSSION}

In the above experiments it seems that two mutations are involved for resistance to oxytetracycline; the first mutation determines an average of resistance to oxytetracycline of about $120 \mu \mathrm{g} . / \mathrm{ml}$. The fact that the first step of resistance might be due to a mutation in a single gene shown from the absence of segregation for resistance when the DNA of strain sB 57 of Bacillus subtilis or of the first peak of the trimodal distribution (Fig. 2) is used. In the second selection cycle for resistance to oxytetracycline, a second mutation was selected, which was synergistic to the first. This new mutation when present alone in a strain caused an average resistance to oxytetracycline $160 \mu \mathrm{g} . / \mathrm{ml}$. and when associated with the first mutation added its resistance to it.

These facts are proved by the genetic uniformity of the DNA from the second peak clone ( $\mathrm{sB} 151 / 5)$, while, from the two-step resistant strain (sB 151) and from the clone sB 151/8 of the third peak, three modes of resistance appear (Fig. 2). Clear evidence of non-random segregation of the two factors also comes from Figs. 2,5 and 6 . In fact, during the experiment, when a mixture of two separate preparations of DNA were used (each one carrying one of the two factors) only four colonies out of 300 showed a resistance of the order of magnitude which one would have expected from the simultaneous presence of two factors. However, in the two cases in which the DNA of the strain resistant to $250 \mu \mathrm{g}$. oxytetracycline $/ \mathrm{ml}$. and of the transformant resistant to $250 \mu \mathrm{g}$. $/ \mathrm{ml}$. was used, the colonies which were highly resistant were, respectively, 67 of 298 , and 81 of 290 . These facts seem to show a $25 \%$ co-transfer of the two factors. It can therefore be concluded that the resistance to oxytetracycline, at least within the limits of the two steps studied in this experiment, is due to two mutations which are closely linked and possess almost complete additivity at the phenotypic level.

\section{REFERENCES}

Cavalli, L. L. \& Maccacaro, G. (1950). Chloromycetin resistance in $\boldsymbol{E}$. coli, a case of quantitative inheritance in bacteria. Nature, Lond. 166, 991.

Demenec, M. (1945). Production of Staphylococcus strains resistant to various concentrations of penicillin. Proc. nat. Acad. Sci., Wash. 31, 16.

Demerec, M. (1948). Origin of bacterial resistance to antibiotics. J. Bact. 56, 63.

Ephrati-Elizur, E. E., Srinivasan, P. R. \& Zamenhof, S. (1961). Genetic analysis, by means of transformation, of histidine linkage groups in Bacillus subtilis. Proc. nat. Acad. Sci., Wash. 47, 56. 
Hotchkiss, R. D. (1951). Transfer of penicillin resistance in pneumococci by the desoxyribonucleate derived from resistant cultures. Cold Spr. Harb. Symp. quant. Biol. 16, 457.

Hotchкiss, R. D. \& Evans, A. H. (1957). Genetic and metabolic mechanisms underlying multiple levels of sulphonamide resistance in pneumococci. In Drug Resistance in Microorganisms. Ed. by G. E. W. Wolstenholme \& C. M. O'Connor. London: J. and A. Churchill Ltd.

Hst, YU-ChIn \& Herriote, R. M. (1961). Studies on transformations of Hemophilus influenzae. III. The genotypes and phenotypic patterns of three streptomycin-resistant mutants. J. gen. Physiol. 45, 197.

Magni, G. E. \& von Borstel, R. C. (1962). Different rates of spontaneous mutation during mitosis and meiosis in yeast. Genetics, 47, 1097.

Nester, E. W. \& Lederberg, J. (1961). Linkage of genetic units of Bacillus subtilis in deoxyribonucleic acid (DNA) transformation. Proc. nat. Acad. Sci., Wash. 47, 52.

RAVIN, A. W. \& IYER, V. N. (1961). The genetic relationship and phenotypic expression of mutations endowing pneumococcus with resistance to erythromycin. J. gen. Microbiol. 26, 277.

Spizizen, J. (1958). Transformation of biochemically deficient strains of Bacillus subtilis by deoxyribonucleate. Proc. nat. Acad. Sci., Wash. 44, 1072.

Young, F. E. \& Spizizen, J. (1961). Physiological and genetic factors affecting transformation of Bacillus subtilis. J. Bact. 81, 823. 